\title{
TECHNOLOGY OF FISH SNACKS BASED ON MINCED FISH USING A PROTEIN SUPPLEMENT FOR PREVENTION OF CHRONIC GASTROINTESTINAL DISEASES
}

\author{
Bogdana Starostenko ${ }^{1}$, Kristina Nechepurenko ${ }^{2}$, Hanna Horbenko ${ }^{3}$, Olena Zolotukhina ${ }^{4}$, \\ Roza Zorya ${ }^{5}$, Andrey Trubchanin ${ }^{6}$ \\ ${ }^{1}$ Department of Chemistry, Microbiology and Food Hygiene, Kharkiv State University of Food Technology and Trade, Kharkiv, Ukraine \\ panikarovadana@gmail.com \\ ${ }^{2}$ Department of Food Technology and Hotel and Restaurant Business, Kharkiv College of Trade and Economics of Kyiv National \\ University of Trade and Economics, Kharkiv, Ukraine \\ hechepyrenko@gmail.com \\ ${ }^{3}$ Department of Food Technology and Hotel and Restaurant Business, Kharkiv College of Trade and Economics of Kyiv National \\ University of Trade and Economics, Kharkiv, Ukraine \\ Klyntik07@gmail.com \\ ${ }^{4}$ Department of Food Technology and Hotel and Restaurant Business, Kharkiv College of Trade and Economics of Kyiv National \\ University of Trade and Economics, Kharkiv, Ukraine \\ Elenazolotyhina79@gmail.com \\ ${ }^{5}$ Department of Food Technology and Hotel and Restaurant Business, Kharkiv College of Trade and Economics of Kyiv National \\ University of Trade and Economics, Kharkiv, Ukraine \\ Zorya_roza@ukr.net \\ ${ }^{6}$ Department of Surgery No. 1, Kharkiv State Medical University, Kharkiv, Ukraine \\ a.trubchanin@gmail.com
}

ARTICLE INFO

Article history:

Received date 11.05 .2020

Accepted date 12.06.2020

Published date 30.06 .2020

Section:

Microbiological and Food industry

D O I

$10.21303 / 2313-8416.2020 .001343$

\section{KEYWORDS}

protein supplement based on fish skin minced fish system

temperature of drying agent

fish snacks

\section{ABSTRACT}

The necessity of developing new energy-saving technologies for integrated deep processing of fish raw materials is substantiated. The results of a study of functional technological indicators of fish minced systems using protein supplements based on salmon skin are presented. Rational parameters of drying fish raw materials are determined, which allow to maintain its high nutritional and biological value. The technology of fish snacks based on dried fish raw materials using a protein supplement from salmon skin has been developed.

Object of research: development of a technology for the production of fish snacks with protein supplement.

Investigated problem: obtaining an affordable food product with an increased amount of protein.

The main scientific results: possible ranges of the concentration of protein supplements in the technological process are identified and the parameters of the production process are determined. It is shown that increasing the concentration of protein supplements reduces the duration of the sublimation process for the production of fish snacks. In particular, increasing the concentration of protein supplements to $15 \%$ makes it possible to increase the amount of mineral and protein substances.

Scope of practical use of the research results: food industry enterprises specializing in the processing of fish raw materials.

Innovative technological product: the technology for the production of fish snacks enriched with protein raw materials can prevent the development of peritonitis and chronic exacerbations in patients with the gastrointestinal tract.

Scope of the innovative technological product: fish processing complex in the field of food production, clinical practice of using fish snacks for the prevention of chronic diseases of the gastrointestinal tract.

(C) The Author(s) 2020. This is an open access article under the CC BY license http://creativecommons.org/licenses/by/4.0).

\section{Introduction}

In the context of the aggravated environmental situation, the issue of public health is particularly acute. It is known that human health is almost $40 \%$ dependent on the quality of food products, in particular, their nutritional, energy and biological value. For several decades, humanity has been suffering from a lack of complete protein, the source of which, as it is known, is mainly raw materials of animal origin, in particular meat, fish, milk and eggs $[1,2]$. 
Food products, namely fish raw materials, can play a positive role in the treatment of postoperative patients, especially for patients with acute chronic pathology of the abdominal organs.

Improper nutrition and inadequate daily diets affect the intestines, forming ulcers, which in turn can lead to peritonitis.

If the daily diet is not followed, chronic diseases become aggravated, Crohn's syndrome occurs, when ulcers appear throughout the intestines, which leads to surgical pathology.

So, fish and fish products, which are rich in high-grade proteins, lipids, polyunsaturated fatty acids, micro- and microelements, positively affect the condition of patients and help to help align the diet in preventive measures.

\section{1. Object of research}

The object of research is the technology for the production of fish snacks enriched with protein raw materials for preventive measures to prevent the development of disorders of the gastrointestinal tract.

\section{2. Problem description}

Studies by many scientists have shown that the rational use of fish raw materials involves its waste-free processing. Wastes from the fish processing industry, represented mainly by collagen-like raw materials, can be a source of valuable proteins [3-5].

Studies of a number of scientists [6-8] have formed several ways out of this situation:

- increase in fish growing and production of fish products;

- attraction of unprofitable fish species to the technological process;

- use of protein concentrates, isolates, emulsions and protein supplements based on fish collagen and raw materials in fish technology.

Today, there is a problem of insufficient implementation of highly effective modern technologies for processing low-value secondary raw materials and waste from the fishing industry; they have significant potential in the creation of food products and additives. In addition, the processing of such raw materials has an environmental and economic aspect, since the use of secondary resources is one of the conditions for the environmentally friendly development of the economy.

In the fish processing industry, several trends are observed: an increase in demand for delicious seafood, including frozen shrimp; narrowing of the market for natural fish products due to their high cost; increase in the assortment of semi-finished products of high degree of readiness and finished culinary products from fish; and also the rapid development of structured and molded products based on minced surimi and minced fish (minced fish products, sausages, fish snacks) [8-10].

\section{3. The proposed method of solving the problem}

One of the new and promising directions of processing fish raw materials is the production of minced fish on its basis $[11,12]$ with the aim of obtaining fish snacks based on them.

Thus, the urgent tasks of the fishing industry in Ukraine are determined by the following promising areas of hydrobiont technology:

- scientific justification and development of integrated technologies for raw materials of water origin, providing for the deep processing of raw materials to produce traditional food products, products prepared to the maximum extent possible (multicomponent minced products, quick-frozen culinary products, fish snacks, etc.);

- development of energy-saving latest technologies that ensure high economic efficiency of their use, quality and safety of products.

The possibility of obtaining a wide range of products from fish raw materials is determined by its chemical composition. Important indicators include fat, protein, enzyme activity, and qualitative lipid composition. Given the protein-water coefficient and the fat content of the fish, all raw materials are classified into groups that are recommended for use for a certain type of product. Thus, it is advisable to use fatty, high-fat and high-protein fish varieties for freezing, drying and smoking; low-protein, low-fat fish should be processed into fodder flour, and low-fat protein fish for the production of frozen and dried products [13-15]. 
In recent decades, the search and development of new areas of using low-value fish raw materials for obtaining dried products has been actively conducted, due to the possibility of extending the shelf life of food products, as well as the popularity of these products on the Ukrainian market [3, 16].

The aim of this research is development of the technology of dried fish snacks based on minced fish with low-value fish raw materials using protein supplements based on fish skin.

\section{Materials and Methods}

To introduce the technology, a study was conducted of water-binding [27] and emulsifying ability [28]. The studies were carried out in laboratory conditions and carried out by the following methods: moisture content - drying the sample to constant weight at a temperature of $105^{\circ} \mathrm{C}$ according to GOST 4288-76 [27]. Determination of the water-binding capacity of the test samples was carried out using the pressing method. It was experimentally established that $1 \mathrm{~cm}^{2}$ of the wet spot area of the filter corresponds to $8.4 \mathrm{mg}$ of moisture. The content of bound moisture, $\%$ of total moisture was determined by the formula:

$$
W B C=\frac{s-w \times 8.4}{s} \times 100 \%
$$

where $s$-total moisture content in the sample, $\% ; w$ - wet spot area, $\mathrm{cm}^{2}$ [27].

Drying of the samples was carried out by the method of studying thermal stability and was determined with a Kett JE-400 thermogravimetric infrared moisture meter, which determines the moisture content and dry residue (\%) in the sample after the change in the mass of the sample after it was dried with an infrared lamp. The principle of measuring Kett JE-400 moisture meters is based on the ability of water contained in a controlled product to absorb light flux energy with wavelengths lying in the near infrared zone. If necessary, the following parameters can be changed: indication (moisture content or dry residue), drying temperature from $65^{\circ} \mathrm{C}$ to $195{ }^{\circ} \mathrm{C}$, drying time up to $90 \mathrm{~min}$ with a step of $60 \mathrm{~s}$ was $45 \times 60 \mathrm{~s}$, as well as the measurement mode. Moisture (2) and dry residue (3) were determined by the formulas:

$$
\begin{gathered}
M_{0}=\frac{W-W_{0}}{W} \times 100 \% ; \\
D_{r}=\left(100-M_{o}\right) \%,
\end{gathered}
$$

where $W$-initial mass of the sample; $W_{o}$ - mass of solids.

The chemical composition [30] was defined as the quality of food products, taking into account indicators such as the energy value of the product is calculated by the mass fraction of digestible proteins, fats and carbohydrates; biological value, which is characterized by the mass fraction of essential amino acids, polyunsaturated fatty acids, vitamins, mineral salts, tonic substances and other biologically active compounds; organoleptic properties: form, appearance, color, texture, smell and taste of the product. The quality of the product as a whole is equal to the sum of all indicators, taking into account the significance coefficient of each of them.

\section{1. Experimental procedures}

The technology of protein supplements based on fish skin using biotechnological techniques are developed [17]. Salmon skin was used as fish skin, and collagenase was used as an enzyme preparation. Protein supplement is characterized by high water-binding and emulsifying ability. In addition, the protein supplement from salmon skin is similar in its organoleptic characteristics to minced fish systems, which makes it promising to use it in fish products technologies, especially based on minced fish.

The developed protein supplement was introduced into the composition of minced fish with blue whiting in the amount of $15 \%$ by weight of the fish. The choice of fish raw materials was primarily determined by its chemical composition. Blue whiting is characterized by a high mass fraction of water and protein, which is $79 . .80 \%$ and $17.3 \ldots 18.5 \%$, respectively, of the total mass of fish, as well as low fat content, does not exceed $1.2 \ldots 1.5 \%[18,19]$. 
Significant protein content in blue whiting meat determines the high biological value of this fish raw material, since fish proteins are easily digestible proteins $(92 \ldots 98 \%$ digestible by the human body) and are characterized by a high efficiency ratio of $1.88 \ldots 1.90[15,19,20]$. At the same time, blue whiting meat is characterized by a low fat content, facilitates the drying process of this type of fish raw material. In addition, a developed protein supplement is also characterized by a high protein content, and its moisture content is close to that of fish stocks. In terms of dry matter, the protein fraction of the developed additive is $90.1 \%$, the lipid fraction is $6.1 \%$, and the mineral is $3.8 \%$, which makes it possible to classify the developed additive as protein [21].

\section{Results}

The chemical composition of fish minced systems using $5 \ldots 15 \%$ protein supplements is given in Table 1. This level of replacement is due to the fact that the introduction of a protein supplement in an amount of less than $5 \%$ does not significantly affect the technological and organoleptic characteristics and biological value of the finished product, and the introduction of more than $15 \%$ leads to a deterioration in organoleptic characteristics and the appearance of limiting amino acids.

Table 1

The chemical composition of the model minced systems

\begin{tabular}{ccccc}
\hline Samples & Moisture, $\%$ & Protein, $\%$ & Fat, \% & Ash, \% \\
\hline Minced fish (control) & $75.1 \pm 0.9$ & $22.2 \pm 0.5$ & $1.10 \pm 0.05$ & $1.6 \pm 0.1$ \\
Minced fish with 5 \% protein supplement & $72.7 \pm 0.9$ & $21.8 \pm 0.5$ & $1.00 \pm 0.05$ & $1.5 \pm 0.1$ \\
Minced fish with 10 \% protein supplement & $76.1 \pm 0.9$ & $21.4 \pm 0.5$ & $1.00 \pm 0.05$ & $1.5 \pm 0.1$ \\
Minced fish with 15 \% protein supplement & $76.5 \pm 0.9$ & $21.1 \pm 0.5$ & $1.00 \pm 0.05$ & $1.4 \pm 0.1$
\end{tabular}

As can be seen from the data given in Table 1, with an increase in the mass fraction of the protein supplement in the composition of the minced systems, there is a slight increase in the mass fraction of moisture and, as a result, a decrease in the amount of solids. These changes are due to the difference in the chemical composition of fish raw materials and protein supplements. The data obtained indicate that the experimental samples do not have significant differences compared with the control sample, confirms the possibility of using the developed protein supplement in the composition of minced systems.

It was found that the BS content of $15 \%$ in minced fish systems makes it possible to obtain softer and more supple systems. This is confirmed by an increase in such indicators as compliance (by $0.25 \times 10^{-3} \mathrm{~Pa}^{-1}$ ) and plastic viscosity (by $6.4 \times 10^{7} \mathrm{~Pa} \cdot \mathrm{s}$ ), as well as a decrease in conditional elasticity (by $73 \mathrm{~Pa}$ ) in experimental samples from $15 \%$ protein supplements compared to controls [22]. In further studies, a stuffing system with a mass fraction of protein supplement of $15 \%$ was used, since this sample is characterized by the best structural and mechanical indicators, in particular, plasticity and ductility.

The main preservative factor during drying, which determines the stability of the food product during storage, is the degree of its dehydration. During drying, the taste improves, becoming more expressive and concentrated, as well as the consistency and appearance of the products. Products dried to a final mass fraction of moisture of 5..12\% and protected from re-wetting do not deteriorate for a long time, since most microorganisms are not able to grow and multiply actively at low values of water activity. Under such conditions, only spores of bacteria and microscopic fungi can survive. Thus, drying at high temperatures (above $100{ }^{\circ} \mathrm{C}$ ) allows to get almost sterile products, but at the same time it leads to the destruction of proteins, tissue enzymes and the decomposition of fats. Considering the above, 2 methods of drying were chosen, namely: drying in an oven at a temperature of $115^{\circ} \mathrm{C}$, as well as drying under mild conditions by the method of mixed heat supply (STP-drying), which will allow to maintain high nutritional and biological value of fish raw materials. 
Minced fish with $15 \%$ protein supplement with moisture content of $76.5 \pm 1.0 \%$ was dried to a residual moisture content of 5.0 $\pm 0.2 \%$. The drying operation was carried out at various temperatures of the drying agent, namely: $50,75,90$ and $115^{\circ} \mathrm{C}$.

As can be seen from the data shown in Fig. 1, the duration of the drying of minced fish at various temperatures of the drying agent was $110,100,80$, and $60 \times 60 \mathrm{~s}$, respectively.

The drying results are shown in Fig. 1.

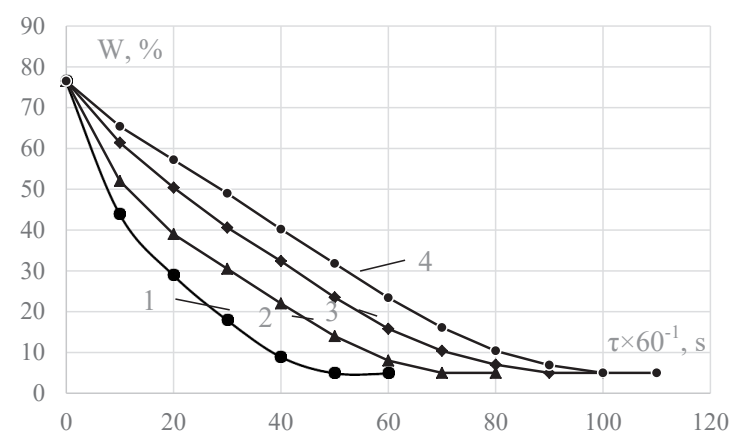

Fig. 1. The dependence of the moisture (W) of minced fish over time $(\tau)$ at various temperatures of the drying agent: $1-115^{\circ} \mathrm{C} ; 2-90{ }^{\circ} \mathrm{C} ; 3-75^{\circ} \mathrm{C} ; 4-50{ }^{\circ} \mathrm{C}$

An analysis of the obtained data indicates that the drying rate at a temperature of $90{ }^{\circ} \mathrm{C}$ is 1.2 times higher than at a temperature of $75{ }^{\circ} \mathrm{C}$, and 1.6 times higher than at a temperature of $50{ }^{\circ} \mathrm{C}$. At the same time, the drying rate at a temperature $115{ }^{\circ} \mathrm{C} 1.3$ times more than at a temperature of $90^{\circ} \mathrm{C}$; 1.7 times more than at a temperature of $75^{\circ} \mathrm{C}$ and 1.8 times more than at a temperature of $50{ }^{\circ} \mathrm{C}$.

Thus, studies have confirmed that increasing the temperature of the drying agent leads to a reduction in the drying time, but at the same time, energy costs increase. In addition, the high drying temperature negatively affects the protein components of the lipids contained in minced fish. Under such conditions, to better preserve the biological value and organoleptic characteristics of the finished products, it is advisable to use the temperature of the drying agent, not exceeding $50{ }^{\circ} \mathrm{C}$.

When modeling the recipes of fish snacks used fish mass and protein supplement in appropriate proportions. The last components were introduced according to technological necessity at the last stage of the process. Recipe for fish snacks using protein supplements based on fish skin are presented in Table 2.

Table 2

Fish snack recipe

\begin{tabular}{cc}
\hline Name of raw materials & Net weight, $\mathbf{g}$ \\
\hline Blue whiting & 1284.0 \\
Protein supplement based on fish skin & 230.0 \\
Salt & 15.0 \\
Ground black pepper & 1.0 \\
Prefabricated mass & 1530 \\
Mass of finished products, $g$ & 100
\end{tabular}

The studies allow to develop a conceptual scheme for the production of fish snacks using a protein supplement based on fish skin (Fig. 2).

As can be seen from the circuit diagram shown in Fig. 2, it includes the following subsystems:

- block C - preparation of prescription components;

- block B - preparation of the recipe mixture, including portioning, formation;

- block A - heat treatment and storage of finished products. 


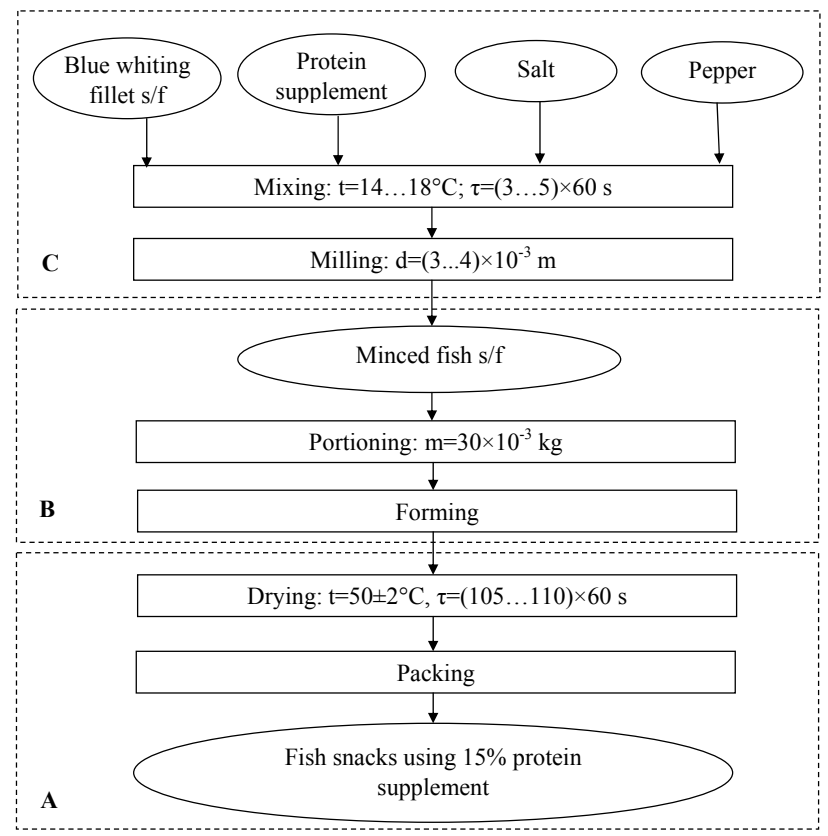

Fig. 2. Schematic diagram of the production of fish snacks using protein supplements

\section{Discussion}

This technology allows to solve the problem of protein deficiency and to carry out preventive measures to spread diseases of the gastrointestinal tract. So, T. Lebska [10] in her study noted the prospects of using fish skin, however, processing took a considerable amount of time and energy, the technology proposed in the article minimizes the complexity of the initial stage of the process, although it relies on the proposed research. N. Dunchenko [11] suggested using more fish raw materials for children's and preventive nutrition, outlining the areas of interest, so it was decided to use snacks. And A. Dvoryaninova [15] proposed an interesting adsorption method, which, in combination with the T. Lebska method, allowed to get fish snacks for smoking with protein raw materials. In contrast, the authors began to study [23, 24], which examined the patterns of assimilation and digestion of secondary fish raw materials in the context of the worldwide problem of food shortages, thus the technology mentioned in the article allows partially solving this problem without additional labor and energy costs.

The authors of $[25,26]$ conducted a detailed study of biological and physicochemical studies of a wide range of fish raw materials, which allowed, based on the above data, to concentrate our research on increasing shelf life.

It is also shown that the use of protein supplements in fish snack technology allows developing resource-saving technology for a new product with a long shelf life.

A limiting factor in the use of a protein supplement is a quantitative factor, since adding more than $25 \%$ leads to deterioration in the organoleptic characteristics of the finished product through a pronounced aftertaste of obsolete fat and fish.

Studies of ready-made in-vitro fish snacks in the intestinal model system are planned to confirm the hypothesis of the prophylactic effect of products enriched with protein raw materials.

Further research will be aimed at determining the functional-technological, physico-chemical and safety indicators of fish snacks.

\section{Conclusions}

Comprehensive analytical studies of the current state and development trends of the fish processing industry, innovative developments of domestic and foreign scientists have made it possible to justify the feasibility and promise of using protein supplements in fish snack technology.

The choice of blue whiting as a fish raw material for the production of fish snacks is justified, which is due to the peculiarities of its chemical composition and biological value.

The regularities of changes in the physicochemical and structural-mechanical properties of minced fish systems using protein supplements were studied, on the basis of which its rational mass fraction was determined $-15 \%$ of the mass of fish raw materials. 
The optimal drying parameters of fish snacks by the method of heat transfer were determined: drying time $-(105 \ldots 110) \times 60 \mathrm{~s}$, temperature $-50 \pm 2{ }^{\circ} \mathrm{C}$.

The technology of fish snacks based on fish raw materials using a protein supplement from salmon skin has been scientifically substantiated and developed.

\section{References}

[1] Tsypriian, V. I. et. al. (1999). Hihiiena kharchuvannia z osnovamy nutrytsiolohii. Kyiv: Zdorovia, 568.

[2] Kizevetter, I. V. (1973). Biokhimiia syria vodnogo proiskhozhdeniia. Moscow: Pischevaia promyshlennost, 423.

[3] Saltanov, D. M. (2011). Tekhnologiia racionalnoi pererabotki gidrobiontov. Vestnik Kamchatskogo gos. tekhn. un-ta, 5, 56-61.

[4] Chudinova, L. L., Antipova, L. V., Dvorianinova, O. P., Grebenschikov, A. V. (2009). Perspektivy ispolzovaniia verkhnikh pokrovov presnovodnykh ryb. Rybprom, 4, 28-32.

[5] Li, Y. C., Zhu, D. Y., Jin, L. Q. (2005). Preparation and analysis of collagen polypeptide from hides by enzymes. Journal of the Society of Leather Technologists and Chemists, 89, 103-106.

[6] Ryzhova, K. I. (2009). Rol i znachennia rybohospodarskoho kompleksu v systemi prodovolchoi bezpeky Ukrainy. Natsionalne hospodarstvo Ukrainy: teoriia ta praktyka upravlinnia, 207-214.

[7] Hrynzhevskyi, M. V., Pekarskyi, A. V. (2014). Optymizatsiia vyrobnytstva produktsii akvakultury. Kyiv: Polihraf Konsaltynh, 328.

[8] Borshchevskyi, P. P., Stasyshen, M. S., Alesina, N. V. (2013). Stratehichni problemy rozvytku rybnoho hospodarstva Ukrainy. Stratehiia rozvytku Ukrainy (ekonomika, sotsiolohiia, pravo), 1-2, 371-387.

[9] Maievska, T. V. (2011). Perspektyvy rozvytku rynku rybnykh tovariv v Ukraini. Tovary i rynky, 12, 53-61.

[10] Lebska, T. K. (2012). Stan ta perspektyvy rozvytku produktsii z hidrobiontiv v Ukraini. Naukovi zdobutky molodi u vyrishenni aktualnykh problem vyrobnytstva ta pererobky syrovyny, standartyzatsii i bezpeky prodovolstva. Kyiv, 12.

[11] Dunchenko, N. I., Igonina, I. N. (2012). Proizvodstvo farsha dlia doshkolnogo i shkolnogo pitaniia - perspektivnoe napravlenie pererabotki rybnogo syria. Aktualnye problemy vyraschivaniia i pererabotki prudovoi ryby. Krasnodar, 88-92.

[12] Rekhina, N. I. (2000). Proizvodstvo, khranenie i ispolzovanie rybnogo mo-rozhenogo farsha. Pischevaia promyshlennost, 3, $46-47$.

[13] Shestak, S. N. (1991). Syre i materialy rybnoi promyshlennosti. Moscow: Agropromizdat, 191.

[14] Cibizova, M. E. (2012). Tekhnologicheskie pokazateli i biologicheskaia cennost malomernogo rybnogo syria Volgo-Kaspiiskogo baseina. Vestnik AGTU. Seriia: Rybnoe khaziaistvo, 2, 182-188. Available at: http://cyberleninka.ru/article/n/tehnologicheskie-pokazateli-i-biologicheskaya-tsennost-malomernogo-rybnogo-syrya-volgo-kaspiyskogo-basseyna

[15] Dvorianinova, O. P., Kalach, E. V. (2010). Innovacionnye tendencii ispolzovaniia miasa presnovodnykh ryb v tekhnologii farsha surimi. Voronezh, 152-156.

[16] Zaiets, V. (2011). Perspektyvy rozvytku kharchovoi haluzi v Ukrainy. Ibcontacts, 7, 3.

[17] Torianik, A. I, Diakov, A. G., Torianik, D. A. (2003). Opredelenie vlagosoderzhaniia v pischevykh produktakh metodom IAMR. Kharkiv: KHGUPT, 20.

[18] Starichkov, A. I. (2000). Strukturoobrazovanie dispersnykh sistem. Pischevaia promyshlennost, 11, 38-40.

[19] Yancheva, M. O., Peshuk, L. V., Dromenko, O. B. (2009). Fizyko-khimichni ta biolohichni osnovy tekhnolohii miasa ta miasoproduktiv. Kyiv: Tsentr uchbovoi literatury, 304.

[20] Kovalenko, V. O., Panikarova, B. O., Chernova, L. O. (2011). Pat. No. 65127 UA. Sposib vyrobnytstva bilkovoi dobavky na osnovi rybnoi vtorynnoi kolahenovmisnoi syrovyny MPK A23L 1/31. No. u201106093; declareted: 16.05.2011; published: 25.11.2011, Bul. No. 22, 4.

[21] Levanidov, I. P. (1980). Vzaimozavisimost osnovnykh komponentov i khimicheskogo sostava ryb. Rybnoe khaziaistvo, 8, 62-64.

[22] Safronova, T. M. (1991). Syre i materialy rybnoi promyshlennosti. Moscow: Agropromizdat, 192.

[23] Skurikhin, I. M., Nechaev, A. P. (1991). Vse o pische s tochki zreniia khimika. Moscow: Vysshaya shkola, 288.

[24] Tilgner, D. E. (1962). Organolepticheskii analiz pischevykh produktov. Moscow: Pischepromizdat, 338.

[25] Kovalenko, V. O., Panikarova, B. O. (2012). Nutritional and biological value of dietary supplements based on collagen raw materials. Eastern-European Journal of Enterprise Technologies, 1 (6 (55)), 49-51. Available at: http://journals.uran.ua/eejet/ article/view/3400

[26] Kovalenko, V. A., Panikarova, B. A. (2013). The rheological characteristics of the protein additive on he base of the fish collagen-contained raw material. Nauka i Studia, 35 (103), 88-95.

[27] Thermo Tech Technologies, Solutions for bio waste, bio solids and municipal sludge (1998). Langley: Thermo Tech Technologies Research Systems Inc.

[28] Karunasagar, I., Karunasagar, I.; Krishnamoorthi, B., Krishnamoorthy, K. N., Meenakshisundaram, P. T., Nayar, K. N. (Eds.) (1995). Shrimp diseases and control. Proc. of the Seminar on Fisheries - A Multibillion Dollar Industry. Madras: Aquaculture Foundation of India, 63-67.

[29] González Siso, M. I., Lang, E., Carrenõ-Gómez, B., Becerra, M., Otero Espinar, F., Blanco Méndez, J. (1997). Enzyme encapsulation on chitosan microbeads. Process Biochemistry, 32 (3), 211-216. doi: http://doi.org/10.1016/s0032-9592(96)00064-7

[30] Chou, H., Huang, C., Wang, C., Chiang, H., Lo, C. (1995). Pathogenicity of a baculovirus infection causing white spot syndrome in cultured penaeid shrimp in Taiwan. Diseases of Aquatic Organisms, 23, 165-173. doi: http://doi.org/10.3354/dao023165 